\title{
THE PRESENCE OF WOMEN IN PARABLES: AN AFROCENTRIC WOMANIST PERSPECTIVE
}

\author{
Ncumisa Manona \\ Department of Religious Studies \\ University of Venda
}

\begin{abstract}
This article will illustrate the presence of women in parables as found in African tradition culture and in the synoptic gospels. Such an illustration will be qualified by examining concurrently the centrality of women in parables and the roles they play. It is important to reiterate that the centrality of women in parables depends wholly on the author's intent. In these parables women are either blamed or praised. Toward the end of this article, the authorial view on women in parables will be challenged.
\end{abstract}

\section{Introduction}

Parables can be found more or less in all cultural settings. As a form of oral tradition, parables are more than merely spoken words, they are a genre of communication that perform a social function. Thus, orality is literature in its own right and it is from orality that other textual literatures emerged.

A vast number of parables occur in Biblical literature and in the synoptic gospels specifically. They are presented to us today in the form of a text. Originally, however, parables were oral traditions. Jesus was no writer but an orator. Parables can thus be viewed as an endeavour on the part of the speaker to influence listeners. Jesus' parables, in particular, reflects the largely agricultural world of his listeners in order to influence and instructs. All his examples are drawn from Galilean peasant life.

Parables have the power to describe everyday life. Nonetheless, whilst they narrate on the level of ordinary life, this ordinariness is put under strain insofar as parables carry within their inner meanings thoughts which seem simple but grow more complex. That is, whilst parables pretend to be plain or trivial, they have the power to embrace the extraordinary. They are more important for what they do not say than for what they say. They encourage but withhold meaning, they suggest but conceal understanding.

\section{Women in African parables}

Since orality is a central communicative strategy in African society, parables are a crucial tool of consolidation. African oral literature is a form that has evolved a special set of principles necessary for the socialization of thought. The spoken nature of literature guarantees the widest circulation of the communal ethic and history. Its preservation and interpretation of history aims at reinforcing powerful and fundamental laws of humanity (see Finnegan 1976). In this sense its symbols are organized to appeal to a complex and varied set of communal emotions.

The above understanding and function of oral literature becomes most plausible when applied to the question of the presence and centrality of women in African parables. In an African androcentric world women are accorded the lowest position and such a position is inherently embedded in African parables.

The image of women as portrayed in African parables reflects a typical woman in a real cultural situation. Women in African parables are either portrayed positively or negatively 
due to their reactions to moral instructions of the society. African parables for the most part thus reflect the manner in which a woman is expected to react or behave in a stringent social code. Various themes related to womanhood are incorporated into African parables because they are deemed suitable for this specific genre.

A closer study of African parables reveals that women feature prominently and are frequently the chief characters. Firstly, they are prominent as storytellers. Storytellers teach morals or convey information. Women therefore functioned to communicate to the young expected behaviour of an African woman. Traditionally, women of advanced age told stories. Furthermore, women assumed these duties due to their closeness to nature. Every storyteller used basic plot cores or themes related to womanhood around which she built stories or parables. As such African parables have a point to make.

There is always a link between the society and the parable. I argue that women told their life stories through parables. Indeed, Mtuze argues that women were given the role of storytellers because they always reflected life as it was and not as they imagined it (1991:72). Hence, there is always a direct correlation between literary characters and reality. African parables depicted a particular view of reality, portraying certain norms, values, and customs. It is for this reason that Amos notes that folklore did not present the entire gamut of cultural ideals and actions of a society, but presents selected domains of themes that were deemed suitable for particular genres of expressions (1975:181). The particular view a culture has of the subject determines its qualifications of inclusion. Nevertheless, parables told by women often supported misogynist themes. They promoted the subservience of women and the domination of men.

Secondly, in the story world of African parables, women form part of the majority of characters. Women were used in African parables to convey certain maxims and truisms that were evidence of the consensus of opinion of the whole society. They were used to instigate events as well as provide solutions in the folktales. Therefore, the focal point of analysis should not be the characters portrayed, but the ideals and values they represented. For example, polygamy is a very popular theme in African parables and is also a very common practice in traditional African society. The storytellers socialized their children about this theme, reinforcing the fact that men in traditional culture could not afford to have only one wife.

In the stringent social codes they were expected to conform to polygamous marriages. Nonetheless, in these marriages women competed for their husband's affection. This might account for male perceptions of women's “viciousness." In polygamous marriages, conflict reigned for some women. They found themselves in conflict and consequently instigated events and solutions. Sometimes, they developed hostility towards one another. Polygamy therefore led to jealousy, witchcraft and cruelty that were all features of negative labelling, that is, bad characterization. Women who developed such tendencies were blamed by the society. Following are the examples of parables showing bad characterization of women.

The parable of UNolenti (Ndibongo, 1986:33), a witch, displays the power of a jealous woman. Nolenti, because of her developed witch-like powers, bewitches a pot. This pot was able to speak, giving instructions, which if carried out without its command would cause death. In this way, Nolenti successfully destroyed two of her husband's, for they were not aware of the fact that the pot was bewitched.

The third wife, however, did not fall prey to the pot and the witch's plot is exposed. Eventually the very pot that was bewitched kills the witch and the daughter. Although the moral of this story is a good one, that is, teaching children not to create bad situations for others and warning that "one bad turn deserves another," it nevertheless succeeded in 
characterizing African women as subservient and encouraged the acceptance of polygyny.

Women are not supposed to feel jealous in polygamous marriages and certainly warned against acting on any such feelings. Whereas polygamy could be viewed as a crime, in this story it is jealousy that is criticized. A woman giving way to her feelings of jealousy developed witch-like powers that overwhelmed her and caused her to lose control. The use of the pot as a central "actor" is in fact an important vessel in a traditional rural life (and modern urban women) and highlights house chores enacted by women, for an example, women- cooking for others. The personification of a pot is not so far fetched if one analyses the important ritual of cooking and feeding, which if not done properly could lead to certain distress and feelings of insecurity.

Once more, it is not a response to polygyny that leads to bad characterization. In the parable of the "women as thieves," a similar labelling is exposed. Scheub (1975:391-95) records the tale of a certain woman who was neglected by her own son and who decided to reside with her son-in-law. Because of hunger, the woman stole sour milk from her son-inlaw and was expelled from his house. Drinking sour milk as a woman at the in-law's home was a taboo in that African tradition, hence the woman was driven out of the in-law's premise.

The woman's expulsion from her in law's home was followed by death at the jaws of a people-eating snake. Because she had a knife with her, she managed to tear the snake's stomach open and the people she found in the snake's stomach were freed. Automatically, the people wanted to show their gratitude by offering her their livestock, but she refused. This story has an ironic twist since the woman's expulsion led to the rescue of other people's lives. Again the cultural standards do not permit a woman to go to other men's homesteads. This woman, though a thief, is the heroine in the story.

Women in African parables are not only labelled as bad. There are some instances women assume positive positions showing good characterization. They are declared "good" if they fulfil their roles as wives as well as mothers. The wife is required to be responsible for her husband and children. She is judged on how she behaves towards her husband and how she looks after him, his household, and his children.

An ideal wife is one who is totally committed to serving the interests of her husband and children, even at the risk of martyrdom or sacrifice (Gaidzanwa, 1985:29). She should therefore be an obedient, submissive, and faithful woman.

An example of a parable portraying good characterization of African women is the parable of Mlengana in a country disabled by poverty (Ndibongo and Ntloko, 1986:57). In this parable there was one homestead that had a cow that was about to calve. Only few days later, after the cow had given birth, the calf was slaughtered. Whenever they wanted to milk the cow they covered a dog with the calf's hide as if it were still alive. The dog went on sucking the cow until the man hit it with a stick. The dog jumped off and the hide fell. The cow saw the dog and became angry and chased the man. While the man was running for his life, a woman shouted at him, telling him to go and sit at the top of a certain stone on which they had played whilst young. In despair and anger, and still feeling flattered cow hits itself against the stone until it died.

The above parable shows the wife coming to her husband's rescue. This is what is expected of a woman in an African culture. If a woman does not rescue her husband she might find herself answerable for his death or injury, and this is what is implied in the above parable.

Scheub (1975:286), a white person who concerns himself with African parables, records another parable in this vein, entitled: "A Boy Getting Pregnant." This parable exemplifies 
the folly and disobedience of a young boy who was sent to fetch medicine for his mother longing for a second child. He was warned not to take any of the medicine for himself but could not resist the temptation. He is made to suffer the embarrassment and discomfort of pregnancy and childbirth. In traditional culture it is a disgrace to see a boy feeding a baby; breast-feeding would be even worse. It is interesting to note that even boys when they have problems turn to their mothers for help and not fathers. Whilst the boy's punishment is unrealistic in its right, it nevertheless has a recognizable justice as well as what might be termed a symbolic function, since it is through her son's misfortune that the boy's mother achieves her longing for a second child.

On the whole, good women in African parables are only good insofar as they fulfil the functions that are required of them in society. A woman is seldom portrayed as good independent of her role as a nurturing figure. Thus women in African traditional culture are subject to many humiliating practices that marginalize them and rob them of their individuality and ambition. Thus, the "good" as opposed to the "bad" needs further definition. It is obvious that good women are held up as examples, even to their own detriment. The so-called bad women, on the other hand, are not criminals, they are merely individuals who fail to live up to the expectations of African traditional society. That is, "bad" and "good" depends on the interpretation of the values of a particular society. Good and bad are not absolutes.

\section{Women in the parables of the synoptic Gospels}

Compared to the literary works of the time, the Gospels contain a surprising number of references to women. As reflected in the Gospels, Christ's action towards women was always supportive and encouraging. He knew their humiliating history. And, after Jesus' death and resurrection, the evangelists likewise felt it important to give attention to women. It is important to highlight that there was a perception of reality that encouraged the evangelists to write about women.

The inclusion of women in gospel literature was significant. Resistance to ideas pertaining to women assuming vital roles in the early church, especially among Jewish Christians was profound. The Gospel writers wanted to know whether faith in Jesus implied a necessary accommodation of or breach with the world of patriarchal misogyny (Cardenas, 1986:51). Of course, they sought their answer in 'Jesus' words. However, each gospel writer projected his own understanding of the ipssisma verba Jesu.

The evangelists' interpretation of Jesus' teachings about women is apparent in the portrayal of women in parables. Although women featured in large numbers, they were only minimally present in the parables. Of the thirty to forty parables in canonical and noncanonical literature, only five depicted women and their world. Most of the characters in early literature are men (Praeder, 1988:100).

Therefore, most parables depicted the relationship and work-worlds of men. Only the parable of the "Judge and the Widow" in Luke and the parable of the "Ten Maidens" in Matthew depicted the relationship of men and women. However, there are no narratives portraying men and women in relationships of partnership. In both narratives, the female counterparts, the "widow" and the "maidens" are cast in subordinate roles. The judge is the centre of the widow's existence, and the maidens whether sleeping or walking exist to meet the bridegroom. None of the parables portray women in dominant roles as mistress.

Parables always supplement one another. In particular, no parable featuring a woman's world occurs alone in a row. Parables set in a woman's domestic world follow parables set in the male world of agriculture or animal husbandry [cf "Lost Sheep" and "Lost Coin" 
parables]. This absence suggests that women and their worlds were assigned complementary, subordinate, or supplementary roles in the story world of the parabolic universe. In the following section I expose the role of women in the symbolic universe of the synoptic gospel parables. Pertinent to this interpreter is the fact that parables always betrayed their social situation. The crucial point they make is always based in their situation in life. That is, the parables and the evangelists always shared the same social background.

\section{Women in the parables of Mark}

Mark was one of the earliest evangelists to record the Jesus tradition. Throughout his literary history, however, there is no trace of the fact that he was ever concerned with the record of women. The absence of specific women parables in his gospel does not mean that he was silent about women. He was no misogynist.

The reflection of women in the Gospel of Mark assumes that women were composite characters in the Markan world. They were part of the audience of Jesus. And, the problem of audience is a poignant one. In the evangelists' rendition, the audience of Jesus is symbolically represented in concentric circles. At the centre was Jesus. Around him were his disciples, viewed as the chief followers of Jesus, followed by his opponents the Pharisees, and the crowd. The disciples and the crowd evoked the composite image of the followers of Jesus. As such, the Gospel of Mark reveals that the Markan portrait of the followers of Jesus is both composite and complex. It is composite in that it does not only include the twelve male disciples, but also the crowd.

Women were part of the crowd of the Markan Gospel. Women shed light on what it meant to follow Jesus and were especially appropriate, according to Mark, for the role of illuminating discipleship (Malbon, 1983:29). Other commentators have suggested that the women of Mark are to be viewed as models of discipleship. Schmitt (1981: 228-33), posits that women provided a positive model of discipleship compared to the negative model represented by the twelve male disciples. On this point, Moltmann-Wendell (1987:110) argues that the Markan perspective highlights the fact that women were in fact the true disciples.

Nevertheless, Munro sees Mark so caught up in the patriarchal Galilean order that he suppressed the discipleship of women (1979:234-5). The positive image of women, therefore, was suppressed by the Markan author due to the androcentric bias of his culture which viewed women in terms of their relationship to men, usually as mothers, wives, or daughters, suggests Munro (1982:225-41). This fact caused the Markan author to relegate women to a position of invisibility in parables.

However, Mark does record how Jesus attended to women and their needs. His account of the healing of females suggested that Jesus did not limit his healing powers to one gender. The public healing of a woman was thus a provocative a provocation act. One can envisage a woman's situation in an androcentric world where deprivation is her status.

In Mark's gospel we have examples of women being praised for faith. The haemorrhaging woman in Mark 5:25-34 emerged from a great crowd that followed Jesus. The presence of this woman, a presence generally obscured by the androcentric nature of the language that the Markan writer uses (masculine forms for all gender), is distinguished from other women and men in the crowd. She is bold and her faith is strong. She reasoned within herself that Jesus' power was such that the touching of his garments would provide healing (5:28). She was proved right. The healing of this woman is unique in the Markan gospel, it takes place solely at the woman's initiative (5:28-29). Jesus feels the flow of power that stops her blood (5:30) and confirms that she will be healed. Schierling points out that the 
haemorrhaging woman suffered as Jesus for she was bleeding for twelve months.

Mark recognizes the suffering of this woman in society as similar to that which Jesus experienced before death. The Markan Jesus brings to an end the haemorrhaging woman's physical and social suffering with no reference to the ritual contamination cited in Leviticus (5:3): "If someone unintentionally touches anything of human origin that is unclean, he is guilty as soon as he realizes what he has done". Physically, the woman was relieved from six to twelve months bleeding. Socially, the Markan Jesus highlighted the symbolic status of the purity and impurity that was thought to defile a person. Indeed, in the first century, women were banned from worship in Canaan during their monthly period.

This sort of ceremonial uncleanliness was considered a major impediment to a woman's full participation in the synagogue. Nonetheless, for Jesus ceremonial uncleanliness was not a problem. It is bold faith, not bodily purity, that is a criterion for fellowship. The woman knew that what she had done was not socially acceptable. However, she acquired a new role in the world of Jesus. It is for this reason that Schierling finds Mark's gospel permeated by a reversal of expectation.

The Syrophoenician Woman in Mark 7:24-30 also characterizes bold faith. The woman reasons with Jesus that Gentiles can be served with no loss to Jews $(7: 28)$, that is, they can be attended to although they are non-Jews, and the Markan Jesus decides that she was right. The healing of the Syrophoenician Woman's daughter is the only Markan healing that occurs at a distance from Jesus. The Syrophoenician Woman's clever reply to Jesus' saying is presented as convincing (7:29). As an outsider, as a Gentile and a woman, she achieves her desire, not so much by a witty remark, but by a faith.

Despite the insult embedded in Jesus' saying, the woman is not put off. She is similar to the persistent widow of Luke 18:1-8. Jesus' willingness to talk to and help this woman is proof of his rejection of the rabbinic teachings concerning discourse with women and uncleanliness of Gentiles (Witherington 1987:65).

Pertinent to the women in Mark's survey is the action of the self-denying woman in Mark 12:41-44, "The Widow's Mite." The widow deposited in the temple collection boxes paltry sum, the smallest in circulation. This incidence might well be understood as an enacted parable parallel to the "fig tree" incident (Mark 11:20-25).

That episode introduced a series of controversies between Jesus and Jewish leaders in the temple, the account of the poor widow's gift closed the series. Great emphasis is placed on the widow's situation in life. She has nothing - no one or anything to count on. What she deposited in the collection box was useless from an economic standpoint. The rich gave a great deal and the abundance of the rich appeared side-by-side with the want of the widow. She gives all and is in striking contrast to the scribes who take all. Nevertheless, she gives something the rich cannot give. For this reason, Jesus points to the destitute widow as a model. Faced with the contrast, Jesus decides to delve into the widow's act versus the scribe's. Jesus drew the disciples' attention to this final act in the temple in order to help them see the importance of the Kingdom of God.

It is from the widow's actions that the disciples learnt about the kingdom of God. The widow does what any follower of Jesus must do to have absolute confidence in God. Jesus called the disciples to gather around him and listen. He used the stock-introducing-formula, "AMEN I SAY TO YOU," which always served a notice of a final outcome or definite answer (Cardenas, 1986:58). For Jesus, what the rich give is religious compromise. They give and risk nothing. What the widow gives is what she has to live on. She gives herself to God altogether. She knows how to offer true worship to God. She then becomes a fully fledged citizen of the Kingdom of God. 
The account of the "Widow's Mite" is a good example of an action parable in Mark. It can be termed "action parable" because Jesus is not using the language of "likeness," but something is happening and later on he explains the incident to the disciples. The Jewish authority is challenged over the widow's offering.

The historical reality of this woman's lower status and the historical reality of women disciples together generally support Mark's characterisation of women who exemplify the demands of discipleship (Parvey, 1974:117-149). Mark's women characters are good and positive because they are bold and self-denying. However, not all women in Mark are depicted as followers of Jesus, just as not all followers in Mark are women.

\section{Women in the parables of Matthew}

Matthew had before him the traditional story of Jesus that was first written by a Markan author. Mark's Gospel was intended above all for those who were not Jews. As a Jew, Matthew wanted to tell the story of Jesus all over again, in his own way for the Jewish community among whom he lived. He wanted to win over Jews to the cause of Jesus. For Matthew, Jesus was the new king of Israel, who rejected his own people in favour of the new church, the new community of Jews and Gentiles (Moltmann-Wendel 1987:122).

Matthew is presumed to have had conservative attitudes of subordinating women to men. There is no doubt that the author of the Gospel of Matthew wrote from an androcentric perspective. Whether the author is male or female, the storyworld embodies patriarchal assumptions. There are many examples that illustrate this pervasive androcentricism. The opening genealogy stands out from the patriarchal background where the man makes history, the birth story centres around Joseph, and positions of power and status, including those of the Jewish leaders and the disciples, are all characterised as male.

Where do women stand in this most Jewish gospel? Examining the position of women in his gospel, Matthew made compromises. Because of his character and his upbringing, he found the stories about women in the gospel of Mark hard to take. But they were so much part of the gospel, of the message of the new church, that he could not ignore them. Thus, one may argue, Matthew had some interest in themes involving women. However, he also stressed an informed and reformed male leadership for the community that followed Jesus. Matthew took a different view about marriage to that which Mark had reported (Mark 10:17). He viewed the husband as the sole arbitrator of divorce since men could divorce their wives in cases of adultery $(5: 32 ; 19: 1)$. It was beyond his powers of imagination that a husband could forgive an unfaithful wife.

Although Matthew shows a discriminatory attitude towards women, specifically the superordination of men over women, he exclusively and explicitly characterize male disciples as being of little faith. By contrast, he says of only one person, a woman, in his gospel, "your faith is great" (15:28). Thus, the theme of male-female reversal (those first becomes last and those last becomes first) is somewhat in evidence in most Jewish of all gospels. Women in Matthew are prominent in stories demonstrating faith. Wire views this as due to the fact that exemplary faith is considered most wonderful where least expected (1991:104).

The "Haemorrhaging Woman" in Matthew 9:20-22 and especially the "Canaanite Woman" in 15:21-28 play important roles. Both women are supplicants and members of the marginalized. The woman with the haemorrhage is ritually unclean. The Canaanite woman is a Gentile. They appear alone with no indication of an embedded status in a patriarchal family. The way they are introduced emphasizes their double marginality. However, both exhibit initiative faith in their approach to Jesus, and the Matthean Jesus highlights their faith. That characterization is typical of the women who came to Jesus for help, but in Matthew's gospel 
the characterisation is extended to include women who are supporters of Jesus.

Nevertheless, even though women play an important part in the Matthean narrative, gender seems to prevent their identification as disciples. For Anderson (1981:16), femalegender in Matthew is paradoxically a strength and a weakness. Gender makes these women doubly marginal, but at the same time, gender heightens their accomplishments. Gender creates a contrast between their model of faith and the failings of those more privileged, such as the Jewish leaders and disciples. Indeed, these women dislocated in any patriarchal family structure show great initiative and are rewarded. Gender, therefore, is not a barrier to faith. In Matthew, the women's role is not unnoticed but is used to challenge others. Observers learn humility and faith from women. Nonetheless, women remain subordinate. The disciples, especially the twelve in Matthew, are topological; they stand for leaders in the Matthean community. Women are only used as examples; no special role is given to them.

In view of Matthew's androcenric bias, Witherington shows no strain in saying, "the Matthean editing of various Markan stories give little or no indication to any attempts to highlight women or their roles" (1990:230). Further, Matthew is not averse to adding material that reflects negatively on women. This is apparent in the only parable about women, the kingdom parable.

The parable of the "Wise and Foolish Virgins" or "Ten Maidens" (25:1-13), unique to Matthew, represents both positive and negative impressions of women. It is singular in both its commendation of some women and its condemnation of others. From the point of view of a study on women and their roles, this is somewhat anomalous (Witherington 1984:41). It is the only place in the gospels where Jesus utters any criticism either directly or metaphorically. The characterization of maidens as wise and foolish is unusual in the parables of Jesus, but characteristic to Matthew in the section of the coming of the kingdom.

This parable manifests the feature of a dramatic parable in Matthew, where human actions and decisions engage the hearers. The drama of the parable comes in contrast to the two groups. The delay of the bridegroom creates the maidens' lack of insight in their preparedness. The wise are prepared and the foolish are unprepared. They sleep and when the bridegroom's arrival is announced they try to remedy the situation, first by asking for oil from the wise maidens, then by seeking to buy oil. Their "foolishness" meets with a double refusal. The other maidens do not share their oil and the bridegroom does not open the door to the wedding feast. According to Via, this is a "tragic parable" in which the central thrust is the failure of the foolish maidens to take adequate preparations (1967:125).

The maidens' failure in the face of the eschaton is as evil as revelling in its delay (Donahue, 1990:105). For Jeremias, the parable illustrates the theme of Jesus' teaching, "it may be too late" and is directed at the Jewish leaders who are delaying in responding to the coming of the kingdom proclaimed by Jesus (1972:174-175).

The tradition that Matthew appropriates often stands in tension with the gospel. It contains some of the most anti-Jewish statements in the New Testament while being the most Jewish in tone and content. Nevertheless, the question still stands: Why did Matthew use women as characters in illustrating the delay of the kingdom? The answer, I suggest, revolves around the role of women as the objects of "shame" and the examples of antiintellectualism in the first century Palestine.

The way Matthew depicts women betrays his traditional culture and socialization. The Jewish leaders' arrogance and inability to respond to the news of the kingdom resembles, for Matthew, a woman's character. Even though Matthew included healings and parables of women in his gospel, he had no intention to elevate them. They stay forever under male dominion. 


\section{Women in the parables of Luke}

With Luke we enter a different world from that portrayed in Matthew and Mark. Luke's gospel emanates less from the mystery of nature or the threat of judgement than from the mystery of human interaction. Thus, the gospel according to Luke emerges out of real life situations. He does not develop his theological concern about Jesus in a vacuum. His treatment of material is evidence of deliberate editorial work influenced by a specific theological hermeneutic.

As Maddox (1982) suggests, like many other gifted writers, Luke felt the urge to express his opinion about subjects that interested him. In 4:16-30, the writer indicates that the liberation of the oppressed and the poor is an essential part of any ministry modelled on the teachings of Jesus. As such, the evangelist of the third gospel is interested in social outcasts and portrays the Lord's deep concern for the ostracized.

Luke shows great concern about riches, poverty, and the use of possessions. References to these matters are frequent. He introduced a substantial amount of material that speaks of Jesus as caring for the disadvantaged. He also gives special attention to those who stand in more need. Johnson (1983:13) maintains that Luke's gospel is for the poor.

The poor are viewed as privileged in the eyes of God. They are among the social rejects and Luke situates his Jesus among them. They are the subordinates and the rich are the super-ordinates. Their situation invites protection, and with the coming of the Messiah we find the reversal of fortunes. Hence, God's news is directed at the poor as blessing and is heard by the rich only as woe. But who are the poor, the needy, and the disadvantaged in Luke?

O'Toole argues that Luke enlightens the reader about women (1984:125). For him, Luke stresses again and again that women were among the oppressed that Jesus came to liberate. He saw their lot as among the disadvantaged of society and wanted his reader to realize that they were the favourites of the Saviour. Right from the beginning of the Gospel, Luke identifies to whom Jesus would direct his activity.

For Talbert, Luke's purpose is evident in the prologue and continues in the entire book (1978:124). In the Magnificat (1:53), Mary praises God for the blessings of the Messiah: "He has filled the hungry with good things, and the rich he has sent empty away." The same Mary describes herself as "the low estate of his hands maid." Luke intends to let us to see Mary as a key link between the life of Jesus and the life of the church. In this way, Luke presents women as active participants in God's Messianic purpose.

Women are thus examples of the lowly exalted as part of an eschatological reversal that breaks into history with, in, and through the person of Jesus. In the first place, the promise of the Saviour to the Patriarchs is now fulfilled through a woman, the one with no social status. Hence, Luke shows without resentment that men and women complement one another. $\mathrm{He}$ displays his interest in male-female parallelism. Luke perceives both men and women working side by side, God's initial intention in Genesis. This is evident both in Luke's noted pairing of parables where men appears first and then women vice versa. These pairs help us to understand further his stance towards women.

Luke points to a man (11:5-13) and to a widow (18:1-8) to encourage the disciples in steadfastness and confidence in prayer. Luke thus unites women to his theme of prayer and illustrates that they, like men, stay in Jerusalem and await the promise of the father. The Lucan author always fashions both men and women in similar roles. The man who loses his sheep goes after it until he finds it (Luke 15:3-7) and the woman who loses a coin sweeps the house and seeks diligently until she finds it (Luke 15:8-10).

The lost sheep and the lost coin are considered twin parables. They play on the contrast 
between man and woman, and perhaps between rich and poor. Indeed, they play on the contrast between the roles men and women assumed in Jesus' time. The Lukan author considered their work for equally good points of analogy to describe the activity of the heavenly father in finding the lost. They could have been cited for their carelessness, though Jesus chose to use each as an example in a positive manner, as an indication of his desire to show that even a fallible man and woman are equally good examples of God's activity.

These Lukan pairs of men and women suggest equality. As Flender (1967:10) concludes, Luke expresses by this arrangement that man and woman stand side by side before God. They are equal in honour and grace and they are endowed with the same gifts and have the same salvific benefits. God, Christ, and the disciples act in their lives in similar fashions.

Furthermore, men and women have similar experiences and fulfil similar functions. They believe and proclaim the gospel message. However, they are alike in their sins. This assumes that Luke's universality, like his attitude towards the disadvantaged in general, depends on God's own attitude. God and Christ show no partiality, unless it was toward the disadvantaged. Women therefore, as members of the secluded group, the second-class citizens with no social status, resume that privilege of being the favourites of Christ.

More than any evangelist, Luke emphasizes Jesus' concern for the widows. The text as it is needs to be seen in relation to much a wider ideology of widowhood. Widows, more disadvantaged than other women, were particular favourites of Luke. Their needy and sometimes pitiable circumstances and their sense of prayer, determination, and generosity stirred his heart. It must be noted, therefore, that Luke wrote his gospel against the background of this social reality. Social security or life insurances did not exist in those days, and for this reason a widow was not well provided for when her husband died. We have an example of the prophetess Anna who lived for seven years with her husband and for the rest of her life, she was a devoted woman who did not leave the temple but worshipped by fasting and prayer day and night. (Luke 2:36-38). She fulfils the definition which the author of I Timothy gives a widow, "She who is a real widow is left alone, has set hope in God and continues in supplication and prayers day and night (I Tim.5:5).

A widow functions in the parable of the "Unjust Judge" (Lk.18:1-8) as an example to the disciples that they ought to pray and not lose heart. The writer's choice of a woman in need of help as an example for the disciple, indicates Jesus' sympathy and concern for this particular group of people in a male oriented society.

In the parable, the narrator presents the related and interwoven issues resulting from unequal social classes and inter-social relationships by using a widow-judge pattern. In the social map of first century Palestine, a widow represented a member of the lowest social class, one without protection and honour. At the same time she is an object of shame. By contrast, the judge was an image of the powerful elite, wealthy, and honoured.

In reality, the significant role of the judge is to maintain justice. He is omnipotent and his position is unassailable. In the first century, judges were expected to serve widows, orphans, and foreigners, as the second-class citizens who made up a special class in need of protection. The interaction between the judge and the widow was meant to be part of the metaphorical system that reflected the understanding and experience of God. Because of the judge's power in society, the widow persistently came to him for vindication from her opponents. Her steadfast determination brought the judge to do his duty. This parable should be seen as a struggle between the widow and the judge, for the widow's legal opponents played no part in the story. Thus what is celebrated in this parable is the woman's attitude and activity in fighting for her rights and that justice be accorded to her. The woman and not the judge gains victory in the end. 
Similarly, Lk.15:8-10 is an interesting example of a parable that involves a woman. Jesus draws an analogy between the activity of a female and God. The behaviour of a woman who turns her house upside down because she lost one coin is seen as a characteristic of God's activity and concern for sinners. This parable should not be seen as an analogy between a woman searching for a lost coin and a person seeking the kingdom (see Matthew 13:34-5). The parable intends to show God's love for the seeking of the lost and his joy over their salvation. Luke emphasizes the aspect of joy and peace that Jesus brought by his coming.

Luke dedicates the whole of chapter 15 to this theme of joy. A shepherd, having found one lost sheep as well as a father, seeing his lost son returning home, invited neighbours to rejoice with him and is indicative. Thus joy, peace, and hope are promised to those whom society rejects.

The parables of the "Lost Coin" (Lk.1: 8-10) and the "Unjust Judge and the Widow" (Lk.18:1-8) are the only parables in the gospel where women are depicted as victorious. Jesus in Luke addresses the lowest social group exemplified in the widow, who is without possession, name, or status. In these two parables, justice is done to a woman regardless of her social position. It is not accidental that the most liberating message to women and the oppressed is summed up in another woman's song, the "Magnificat." What significance does this song have in Luke? It shows that in the dispensation of Jesus' reign there will be no distinction between the rich and the poor as in the case of the unjust judge and the widow. Such class distinctions as exist in the parable will not exist in future because people will all be alike. For the kingdom to be established, disciples have to persevere in prayer as the widow of the parable did. They should believe that their prayers will be answered because God is waiting to give his children the gift of love, unlike the unjust judge, who acted on behalf of the widow out of convenience.

By and large, women in Luke, especially in the parables, serve as good examples to follow. Luke had a gentle heart towards them and his gospel can be alternatively called the gospel of women. He elevates women from the beginning to the end of his gospel. He placed them firmly on the stage of the drama of redemption and let the light of eternity shine on them. In this way, Luke made women examples of his soteriological framework (Van der Walt, 1988:27).

\section{Similarities and dissimilarities in the parables concerning women}

The fact that women play a subordinate role in all socio-cultural backgrounds cannot be denied. Whoever wrote about women and their roles wrote under the intense pressure of androcentric bias on ideas pertaining to women. Such a person therefore either wrote as a deviant to androcentric norms and values to elevate women or wrote as an oppressor, intensifying women's situation in a male oriented world. One can talk of a honour/shame pattern visible in parables. Intrinsic in all these parables is either praise or blame.

In African parables and the parables according to Luke, women played a central role. However, their centrality in these parables does not automatically suggest that they were honoured. Luke exceptionally portrays them positively. He shows no qualms in honouring them. His attitude toward women was then unique and he was surely opposed to the views and attitudes prevalent in his time.

However, for Luke women yield the way and alter the situation so stifling for them. For instance, the news of the birth of the saviour was brought to Mary personally (Lk 1:28-35). Once more, Elizabeth qualifies in her prophecy a new dispensation where women, and not men make history. All justification of the intent to subjugate a person by reason of sex has vanished, (Cardenas, 1986:53). 
As such, Luke treats people of both sexes as people, responsible individuals each with their own talents, needs, and failures. This is apparent in the twin parables of the "Lost Sheep" and "Lost Coin", where both man and woman carelessly lost their possessions but are both depicted as victorious.

In the parable of the persistent widow a woman is praised by showing strong character by pestering a judge in doing his job. Women characterization in Lucan parables is therefore absolutely impressive and could not be matched with any other women parables.

Parallel to the Lukan parables about women are African parables. Although women also play a central role in these parables, they differ considerably. These parables are in no way trying to elevate women. Women in African parables are only employed to perpetuate and depict men's views as some kind of reality on how women are supposed to conform in their world. Viewed in this manner, women in an African society will stay forever under male domination. However, some women characters in these parables show initiative in trying to sort their way out of the situation, (Ndibongo, 1986:33). Unfortunately, women of this character are blamed by the society and as such are silenced. It is only when they comply to so called "social etiquette" that they are praised. Thus, women parables in an African traditional culture intensify women's oppression where the phrase 'woman' is always read to indicate or to mean "those who enjoy incomplete rights" in a patriarchal society. Nonetheless, women in these parables are the ones who preach the gospel.

Unlike the Lukan or African parables concerning women, Matthew in his only parable about women, "The Ten Maidens" (Mtt 25:1-13), had a split decision. He did not want to praise or blame women outright. Half of the women were portrayed as "wise" and the other half as "foolish."

Therefore, Matthew does not take a real stand on women's presupposed roles. He does not commit himself to women. He fits neatly with the male chauvinists of his time who considered it absurd to place women and men on the same plane. He simply makes use of women as examples in showing the situation of the end of time. One may ask therefore why did he have to involve women in his end of time parable: what about the present time? Where were these invisible, shadowy little creatures during Jesus' birth, His earthly ministry, and death parables? Again this shows Matthew's lack of interest in women characters. For him women were far from making history, the world as it was remained a men's world. Men will always be at the center of history, sociologically, ideologically and politically.

\section{Summary and conclusion}

Parables are understood as the language of conflict that at the same time rectifies the situation. In a culture in which women are not supposed to be seen or heard, one learns, especially in parables, more about their roles. Thus in parables women are employed by different authors in different situations for different reasons. The author concerned either elevates women or consolidates their position in a patriarchal nourished society.

As portrayed in African parables women play a central role that at the same time is subordinate. They are central in that they pioneer African parables both as storytellers and characters, with a duty of reinforcing to the young ones as well as other women the codes of conduct and expected behaviour towards males in an African world. Thus the African society through parables impedes women's position and they remain subordinates.

The synoptic gospel parables have their origin in Jesus' tradition. And, Jesus exceptionally deals with women so tenderly as a result the gospel writers were to set their standards from him. All the gospels showed women's strong character, the faith and initiative of the marginal. They revealed greater perseverance, greater loyalty and greater 
faith than even the twelve. Such women altered the situation, for they do something unusual in a male oriented world. This entails the Haemorrhaging and the Syrophoenician woman in both Mark and Matthew and the widow in Luke as good examples.

However, as far as the parabolic stories are concerned, Mark among the evangelists did not concern himself with women parables. Probably Mark was caught up in the androcentric bias of his society. His gospel is declared a parable on its own, since other evangelists drew information from him and took all the pain to reinterpret it. Nevertheless, some evangelists shared the same sentiments with those of Jesus concerning women in their parables. Luke appropriated so explicitly women's equality to men and her new assumed roles in society, in his parables. In his work Luke highlights that mere chronological priority does not mean anything and emphasizes the theme of the reversal of fortunes.

Irrespective of the fact that Matthew depicted women in parables, he did not share the same values for elavating women as Luke in his parables. For him, women remained under male rule. At any rate, he did not want to come out clearly in oppressing women though his work insinuates women's oppression. His only woman parable was neutral about women. In the same parable he praises and blames women alike. Nevertheless, none of the two groups assume roles of power.

\section{REFERENCES}

Cardenas, PJ 1986. The Poor man called Jesus. Maryknoll. New York: Orbis.

Donahue, SJ 1988. The Gospel in parables. USA: Fortress Press.

Finnegan, RH 1976. Oral literature in Africa. Nairobi: Oxford University Press.

Gaidzanwa, RB 1985. Women in literature. Zimbabwe, Harare: College Press.

Jeremias, J 1963. The parables of Jesus. London: SCM Press.

Johnson, LT 1981. Sharing possessions: Mandate and Symbol of Faith. Philadelphia: Fortress Press.

Maddox, R 1982. The purpose of Luke-Acts. Edinburg: T\&T Clark.

Malbon, ES 1983. "Fallible Followers: Women and Men in the Gospel of Mark". Semeia 28(29-48).

Moltmann-Wendel, E 1987. The women around Jesus. London: SCM Press.

Mtuze, PT 1991. "Female stereotyping in Xhosa prose fiction and folktale". South African Journal of African Languages 11:2.

Munro, W 1979. Biblical affirmation of Women. Philadelphia: Westminster.

Munro, W 1982. "Women disciples in Mark". Catholic Biblical Quaterly (225-41).

Ndibongo, WPT 1986. Ezinge Iintsomi zamaXhosa.

O' Toole, RF 1984. The Unity of Luke's Theology. Delaware, Wilmington: Michael Glazier.

Parvey, CF 1974. " The Theology and leadership of women in the New Testament." Religion and Sexism. ed. Reuther, R. R New York: Simon \& Schuster.

Praeder, SM 1988. The word in women's world: Four Parables. Wilmington: Michael Glazier.

Scheub, S 1975. The Xhosa Ntsomi. Oxford: Clarendon Press.

Schmitt, J 1981. "Women in Mark's Gospel: An early Christian view of of the role." The Bible Today. 19(228-233).

Talbert, CH 1978. The perspective on Luke-Acts. USA: T\&T Clark.

Van der Walt, BJ 1988. The Bible as an opener on the Position of Women. RSA: 
Potchefstroom.

Via, DO 1974. The Parables. Philadelphia: Fortress Press.

Wire, AC 1991. "Matthew: Women in an agrarian society - Gender roles in scribal society." Social History of the Matthean community, in ed. Balch, DL.

Witherington, B 1987. Women in the ministry of Jesus. Cambridge: University Press.

Witherington, B 1990. Women and the Genesis of Christianity. Cambridge: University Press. 